\title{
MODERNIZATION OF PROFESSIONAL TRAINING OF THE FUTURE TEACHER OF PHYSICS ON THE BASIS OF CONTEXTUAL APPROACH
}

\section{Ivanytsky 0. I.}

\section{INTRODUCTION}

Innovative learning in a modern institution of higher education should be considered as a process that greatly contributes to the creation and formation of the subjective conditions that make possible the future creativity of both teachers and students in the learning process. The implementation of the Laws of Ukraine «On education» $(2017)^{1}$ and «On higher education» $(2014)^{2}$ is also taking place through significant changes in the content and programs of professional training of future specialists in institutions of higher education. Within the framework of the competence approach, the creation of higher education standards for all branches of knowledge was carried out, the development of educational programs containing a list of graduate competencies and the normative content of training of applicants for higher education, formulated in the terms of learning outcomes, was carried out. Adopted in 2018 «Concepts of development» emphasizes the existence of an imbalance «between the public demand for highly qualified teachers, the prospects of development of society, global technological changes and the existing system of teacher education, as well as the level of readiness or ability of modern teachers to perceive and implement educational reforms in Ukraine» ${ }^{3}$. One of the ways to overcome this imbalance is to modernize the content and structure of professional training of future

1 Закон України «Про освіту» від 05.09.2017 № 2145-VIII. URL: zakon.rada.gov.ua/ go/2145-19.

2 Закон України «Про вищу освіту» від 01.07.2014 № 1556-VII. URL: zakon.rada.gov.ua/go/1556-18.

3 Концепція розвитку педагогічної освіти. URL: https://mon.gov.ua/storage/app/ uploads/public/5b7/bb2/dcc/5b7bb2dcc424a809787929.pdf, c. 4. 
teachers of physics on a contextual basis with the involvement of quasiprofessional and vocational training with the contextual approach.

\section{Methodological features of the contextual approach in the training of future teachers}

The main directions of the restructuring of the higher pedagogical school, outlined in the regulations, reflect the objective trends of development, clearly manifested in the best teaching experience and led to the emergence of new forms, methods and tools, and with them new technologies of professional training of future teachers, new forms of activity of students, carrying innovative teaching and innovative models of pedagogical activity. All forms of activity of students, such as participation in solving of problem situations, modeling contradictions of pedagogical practice in classroom conditions, job as a teacher in the business game, in the «teaching staff» of the training group, the experimental site schools, preparation of the graduation project on the real pedagogical subject, and in some cases introduction of its results in the teaching practice in the author system of activity, are elements of contextual learning.

As shown by A. Verbitsky and his followers, the content of contextual learning is not only the subject side of future professional activity, given by the system of educational tasks, models and situations, but also its social side, reproduced by various forms of joint activity and communication ${ }^{4}$. The student assimilates the subject content of training (general and professional competence, experience of a physics teacher) and, taking a certain position in the system of interaction of participants of the educational process, follows the accepted norms of social relations and actions to the extent that he or she is active and is brought up as a person. The researchers substantiated active teaching methods, developed psychological and didactic principles of business game as a form of contextual learning, implemented in general engineering

\footnotetext{
${ }^{4}$ Вербицкий А. А. Активное обучение в высшей школе: контекстный поход. Москва : Высшая школа, 1991. 207 с.; Вербицкий А. А. Контексты содержания образования. М.: РИЦ МГОПУ им. М. А. Шолохова, 2003. 80 с.; Вербицкий А. А. Концепция знаковоконтекстного обучения в вузе Вопросы психологии. 1987. № 5. С. 31-39.
} 
courses $^{5}$ and practice of training future teachers of physics ${ }^{6}$. The contextual approach to the professional training of future teachers of physics is a consistent combination of the traditional study of humanitarian and socio-economic disciplines with the integration of educational, scientific and pedagogical activity of students, which is an implementation of a dynamic model of their learning activities from the academic activities of the academic type (in lecture form) through quasiprofessional (role-playing and business games) and pedagogical (scientific research, pedagogical practice) to actually teaching.

The basic unit of activity of the student and the teacher in contextual training becomes not «a portion of information», and the pedagogical situation in all the subject and social uncertainty and inconsistency. The system of problematic pedagogical and methodological situations allows to develop dialectically contradictory content of teaching in dynamics and thus provide objective prerequisites for the formation of theoretical and practical pedagogical thinking of the future teacher of physics. By conditioning the dialogical relations of students included in the situation, such content contributes to the formation of their social qualities, since any subject action acquires the quality of an act that is characterized by a varying degree of personal responsibility, aimed at other people, is subject to the accepted norms of relations and provides for the actions of other people. Social sense appears in the actions of future teachers, social and pedagogical attitudes are formed ${ }^{7}$.

The developed model of contextual learning is characterized by a significant expansion of the content of propaedeutic pedagogical training of future teachers of physics, the creation of additional opportunities for individualization of training (through the introduction of elective subjects), the widespread using of pedagogical and methodological

\footnotetext{
${ }^{5}$ Чернилевский Д. В. Дидактические технологии в высшей школе. Москва :ЮНИТИДАНА, 2002. 437 с.

${ }^{6}$ Іваницький О. І. Інноваційні технології навчання фізики. Навчальний посібник. Запоріжжя : «Диво», 2007. 99 с.; Іваницький О. І., Ткаченко С. Г. Технології навчання фізики: навчальний посібник. Запоріжжя : ЗНУ, 2010. 252 с.

${ }^{7}$ Іваницький О. І. Формування соціокультурної компетентності майбутнього вчителя фізики на засадах контекстного підходу. Збірник наукових пращь Кам'янець-Подільського начіонального університету імені Івана Огієнка. Серія педагогічна. Кам'янецьПодільський : К-ПНУ, 2011. Вип. 17. С. 273-278.
} 
situations and tasks as the core of acmeological technologies of professional training of teachers of physics.

The organization of the educational process and further improvement of the model provided for the following activities:

- introduction of a professionally oriented propaedeutic course «School physics» in 1-2 courses to orient students to a conscious choice of educational trajectory, taking into account personal interests (to fundamental physics knowledge or to the professional activity of a physics teacher), and to realize self-rating of their own cognitive abilities;

- a more thorough analysis of the content of the training material «A practical work of school physics experiment», complex «The theory and methods of teaching physics» and special courses to prevent possible duplication, as well as to determine the possibility of wide application of contextual learning;

- during the development of special disciplines courses, the acquired level of general scientific training of the future teacher of physics was taken into account. It contained both the composition of the acquired knowledge and the level of intellectual development of students;

- more rational using of time allocated for teaching practice, maximum coordination with the following educational process is;

- wide using of the method of modeling the professional activity of the teacher of physics in the educational process in order to provide practical training in the classroom ${ }^{8}$.

In the study of the special course «Innovative technologies of teaching physics in secondary school» a count of the current progress was carried out in the form of modular accumulated and final grades due to the using of acmeological technology of training future teachers of physics. The count of results of educational activity of each student was carried out by the teacher according to the schedule of studying of a

8 Іваницький О. І. Моделювання професійної діяльності у фаховій підготовці майбутнього вчителя фізики. Зб. наук. праць К-ПНУ. Серія педагогічна / редкол.: П.С. Атаманчук (голова, наук. ред.) та ін. Кам'янець-Подільський : К-ПНУ, 2013. Вип. 19. C. 277-280. 
special course on the basis of a scale of estimates for performance of various types of educational tasks.

An important role in the organization of contextual learning played level tasks. There were the tasks of reproductive and productive levels of complexity and methodological tasks of three levels of complexity: reproduction, application and transformation.

Performance of theoretical and methodical tasks of reproductive level required reproduction of the knowledge acquired at lectures, seminars of academic type and during the independent work of students. Theoretical and methodological problems of productive level of complexity oriented students on the ability to apply the acquired knowledge. Methodological tasks of the level of transformation provided for the using of knowledge by students in complicated situations (search and creative tasks).

There are some examples of tasks of the appropriate level, which were considered at seminars after self-study students.

Reproductive level

Theoretical problem

1. Prepare a report about «Types and organization of extracurricular activities in physics»».

2. Find out the questions «General issues of planning the educational process in physics»».

\section{Methodical tasks}

1. Develop a detailed program of one of the extracurricular activities.

2. Make a list of wall tables, diagrams and drawings needed to study the issue of «electric current in semiconductors».

Productive level

Theoretical problem

1. Prepare a report «The concept of energy and methods of its development at different stages of the study of physics».

2. Open the question «Scientific and methodological foundations of the study of mechanical vibrations and surges»».

Methodical tasks

1. Prepare a fragment of the lesson about «The Ohm's Law for the full chain».

2. The student formulated the definition of oscillatory motion: «Oscillation is a periodically repeated movement of the body in opposite 
directions». Analyze this definition. If it is not accurate, give counterexamples that would convince the student of this. Make the necessary adjustments, if it needs.

The level of transformation

Methodical tasks

1. Prepare a fragment of the lesson about «The application of Newton's law II to problem solving» taking into account the differentiation of students in the class at levels A, B and C.

2. Give specific examples of the application of technology problem teaching physics to the study of optical phenomena.

Control sections consisted of three tasks of three levels of complexity. We give examples of such problems.

1 control slice

Option 1

1 b. 1R. What are the elements of the structure of educational activities.

3 b. $2 \mathrm{P}$. Highlight the role and place of seminars in the system of organizational forms of training.

6 b. 3T. Prepare, using the program and the textbook of physics for the IX class, a lesson summary on «Newton's First law».

\section{II control section}

Option 3

$1 \mathrm{~b} .1 \mathrm{R}$. Define the technology of teaching physics.

3 b. 2P. Taxonomy of learning objectives in physics and their relationship with learning technologies.

6 b. 3T. Develop logically agreed fragments of introductory and operational-cognitive blocks of modular technology of teaching physics on the topic «Fundamentals of kinematics».

According to our research, students' confidence in the proposed system of contextual learning increases significantly if they practice broad involvement in reasoned mutual and self-assessment of their contextual activities. This is evidenced by the results of the survey of students, $82 \%$ of whom spoke for the evaluation of work in pairs and $74 \%$ is for self-assessment.

It is essential for the teacher to provide a clear feedback with each student in the process of studying the discipline, motivation of 
professional orientation of training of the future teacher of physics, formation of transparent and clear uniform requirements for the knowledge and skills of students, forecasting the course of the educational process.

On the pic. 1 the model of realization of contextual approach in professional training of the future teacher of physics is presented. Changing the structure of training of future teachers of physics on the basis of context is based on three variable modifications of the educational process with the using of context approach. A. Verbitsky identified three basic forms of activity and transition from one basic form to another ${ }^{9}$. The basic forms include academic activities, quasiprofessional activities, educational and professional activities. It determines the modifications of the contextual approach in the process of its application to the training of future teachers of physics.

The first modification of the contextual approach is based on the form of teaching of academic type, which takes place in the study of fundamental subjects, such as Physics, Mathematics, Chemistry, Computer science, courses of theoretical physics. Academic form of training such as lectures or seminars reproduced mainly in the actual educational activity. But here, especially at a problem lecture or seminardiscussion, the context of professional activity is outlined:

The second modification of the contextual approach realizes in the study of professionally oriented cycle of training of future physics teachers, such as pedagogy, psychology, theory and methods of teaching physics etc. Fact kvaisi activities of students is to recreate the classroom in terms and language appropriate pedagogical disciplines, conditions and the nature of the real educational process of teaching physics in secondary school, attitudes and actions of teachers and students. The most striking form of quasi-professional activity is business play and other forms of play. Here the subject and social content of future pedagogical activity is successfully modeled, its context is set.

\footnotetext{
${ }^{9}$ Вербицкий А. А. Активное обучение в высшей школе: контекстный поход. Москва : Высшая школа, 1991. 207 с.
} 


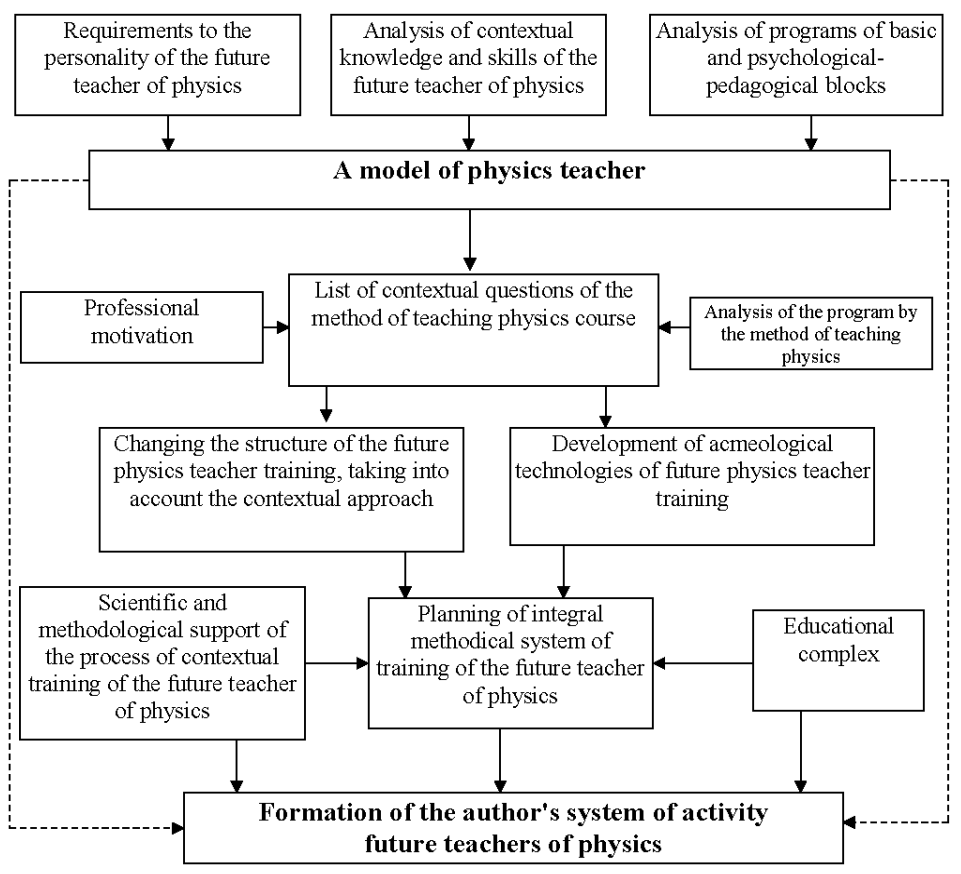

\section{Fig. 1. Model of realization of contextual approach in preparation of future teacher of physics}

The third modification of the contextual approach implements in the system of research work of students (RWS), pedagogical practice and diploma design by implementing the form of educational and professional activity in which the context of the content of training as it merges with pedagogical activity in the form of the author's system of activity of the future teacher of physics or at least its essential elements.

Experience in the implementation of the contextual approach confirms its positive qualities for both students (future physics teachers) and teachers.

Analysis of the using of contextual learning has shown that its application is a logical step in the functioning of acmeological technologies of training teachers of physics and creates conditions for the 
objectification of diagnostics of the formation of professional knowledge and skills of students.

Participating in the scientific and pedagogical research, working as a teacher of physics at school in the framework of pedagogical practice, students remain in the position of students and at the same time really teach students, learn new things and apply their knowledge. As a transition from one basic form to another appear all the latest forms. There are aboratory and practical training, simulation of the educational process in physics and teacher activities, analysis of specific pedagogical situations and problem-methodical tasks, playing the roles of teachers and students, special courses and special seminars, course design ${ }^{10}$.

The experience of applying the contextual approach to the training of future teachers of physics shows that it encourages students to systematic learning, stimulates orientation to higher levels of assimilation and better quality of training of future teachers of physics. The application of the contextual approach aims students at independent planning and correction of their own educational trajectory constantly puts before the choice of tasks of different levels of complexity. Constant comparison of student self-assessment with the assessment of fellow students and teachers increases the efficiency of self-control, positive implementation of the Self-concept, increases self-regulation of their own learning activities.

\section{Providing contextual control and evaluation component of professional training of future teachers of physics}

The phenomenological approach to the analysis of goals, objectives and results of implementation of different variants of knowledge assessment prevails in the methodology of physics. However, pedagogical theory, along with the descriptive function, is also endowed with an explanatory one. The implementation of this function involves a comprehensive essential analysis of these phenomena, which focuses on

10 Іваницький О. І. Моделювання професійної діяльності у фаховій підготовці майбутнього вчителя фізики. 3б. наук. праць К-ПНУ. Серія педагогічна / редкол.: П.С. Атаманчук (голова, наук. ред.) та ін. Кам'янець-Подільський : К-ПНУ, 2013. ВиП. 19. C. 277-280.; Іваницький O.I. Професійна підготовка майбутнього вчителя фізики в умовах інформаційно-освітнього середовища: монографія. Запоріжжя: ЗНУ, 2014. 230 с. 
the identification of internal connections and relationships, the search for the causes of a particular nature of their occurrence. One of the directions of the explanatory function of the theory and methods of teaching physics is the using of contextual approach in the process of methodological training of future teachers of physics.

The main condition for the professional development of the future teacher of physics is the new quality of his training for professional activity, which is caused by such provisions:

* awareness of novelty of requirements of social and economic development of society to the quality of professional training of teachers of physics;

* understanding the importance of the quality of preparation for the professional activity of a physics teacher as an important factor in the harmonization of relations between the individual and society;

* insufficient development of methodology and theory of assessment of quality of training of the teacher of physics at various stages of its professional formation in the conditions of step system ${ }^{11}$.

The research monitoring and evaluation components in the training future teachers of physics is devoted to the work of P. Atamanchuk, A. Bugaev, S. Goncharenko, V. Ilchenko, E. Korshak, P. Samoilenko, O. Sergeeva, I. Filipenko, etc. However, the contextual approach to the control and evaluation aspects of the educational process in these studies was considered in passing. So, in this paragraph of the monograph we deal with the problem of control and evaluation activities of the teacher and the students in the contextual approach to methodical training of future teacher of physics. The aim of the study is to develop methodological foundations of control and evaluation components of the process of professional training of future teachers of physics in the context of contextual learning, taking into account the peculiarities of the implementation of phenomenological and essential analysis. The objectives of the study are:

${ }^{11}$ Іваницький О.І. Професійна підготовка майбутнього вчителя фізики в умовах інформаційно-освітнього середовища: монографія. Запоріжжя: ЗНУ, 2014. 230 с. 
1) to study the features of the traditional system of control and evaluation of students' knowledge in terms of phenomenological and essential analysis of the process of preparing a future teacher of physics;

2) to develop methodical bases of control and estimation of methodical knowledge and skills of students in the conditions of application of contextual approach to the professional training of the future teacher of physics.

With the contextual approach, we considered the assessment of the quality of professional training of the future teacher of physics comprehensively and provided for the formulation and solution of the submitted questions:

- how to organize the educational process in the study of the subject in order to achieve the planned goals of preparing the future teacher of physics for the introduction of innovative technologies of teaching physics in the high school;

- what technological knowledge and skills should be formed and evaluated by future teachers of physics by means of a special course;

- what is the basis for choosing a system of indicators to assess the quality of training of future teachers of physics.

The disadvantages of the traditional system of knowledge evaluation are its subjectivity and randomness caused by the content of the questions and objectives of the examination cards of different complexity: a single question requires a full answer in fact of knowledge, the other full knowledge of the many topics of methodology of teaching physics, the third requires a disclosure of only the basic concepts, fourth refers to the final part of this section encourages the students generalize the knowledge. The study of the course of theory and methods of teaching physics in our practice is contextual, whereby the student's answer must be based on his or her own pedagogical experience gained during the contextual learning and pedagogical practices of different types. The third question of the card is methodical tasks, it is substantially based on certain real pedagogical situations during training in physics, and its solutions provide methodical alternatives. Let's give a concrete example of such methodical task: at a lesson of generalization of knowledge on a subject «Light phenomena» (8 class) students expressed the following statements: 
1. The angle of incidence is bigger than the angle of refraction.

2 If a subject is behind the double focal length of the convex lens, its image will be between the focus and the double focal length.

3. A parallel beam of light after passing through the lens is collected in focus.

4. A transparent body bounded by curved surfaces is called a lens.

5. We do not see this point, so we call it an imaginary point.

Specify the errors and inaccuracies that students have made.

The objectivity of the assessment is involuntarily influenced by the style of relationships between the specific participants of the educational process and the behavior of the student, and the communicative qualities of the teacher and students, and much more. Perhaps the manifestation of the so-called contrast effect, when the grade depends on the impression created on the teacher by previous students. So, an ordinary answer may look even worse against the background of a previous excellent answer and, conversely, gains if the latter was unsatisfactory. The introduction of contextual elements largely removes these problems, making the evaluation criteria more obvious and accessible to the students. Because the system of knowledge assessment must meet the criteria of simplicity, accessibility and unambiguity, i.e. be understandable to the student. It is important that he or she would be convinced of its adequacy, that is, the assessment of compliance with his level of knowledge, the student must understand the legality and fairness of the actions of the teacher (to the students whom levels of knowledge are different can not be applied to the one evaluation criteria).

Thus, being an integral stage of the pedagogical process, phenomenological analysis should not complete it. It should provide for the transition to the essential analysis based on the facts, to reveal the causes of phenomena, to identify the nature of the relationships between them using historical analysis and predict what may happen in the future. It is important at a time when one-sided empirical analysis and assessment of the situation in education is sometimes done outside the context of the socio-cultural unit ${ }^{12}$.

12 Попков В. А., Коржуев А. В. . Дидактика высшей школы. Москва : Издательский центр «Академия», 2008. 224 с. 
The specific analysis in pedagogical research is the critical-reflective analysis appealing to the essential approach. It is characterized by dynamic thoughts, the ability to critically approach both its own conclusions and various sources of «external» information, the ability to see in the subject of research such properties and features that are invisible in a superficial analysis.

As an illustration of what has been said, we present the conclusion that is often found in many studies. It shows that in teaching the theory and methods of teaching physics should be avoided dogmatic presentation of the material, reports without logical conclusion, further explanations and confirmations ${ }^{13}$. However, not all studies performed by researchers at different stages of formation and development of the theory and methodology of teaching physics can be reproduced even in a simplified model version. And the background of the study of the theory and methods of teaching physics is often the teacher's account of the level of knowledge of students of the general course of physics, alternative approaches to the interpretation of the mechanisms of cognitive processes in psychology and pedagogy. It often requires a waste of time, and therefore inevitably part of the material the teacher delivers ready-made, shifting the emphasis on the explanation of the various aspects of the presentation of the material by the teacher and its assimilation by students, especially the formation of concepts in various specific cases. Therefore, the essential approach and the associated critical-reflective style of thinking do not provide an absolute rejection of dogmatism in the educational process, and the reduction of the latter to a reasonable minimum.

Similar contradictions are found in the absolutization of the principle of logical and historical unity in determining the content of the material of the school course of physics, the sequence and depth of its consideration. The contextual approach in the study of the theory and methodology of teaching physics is impossible without the knowledge of

13 Дмитриева В. Самойленко П. Модульная технология обучения и контроль результатов учебной деятельности по физике. Наукові записки Кіровоградського державного педагогічного університету імені Володимира Винниченка. Вип.. 66. Серія: Педагогічні науки. Кіровоград : РВВ КДПУ ім. В. Винниченка. 2006. Ч. 1. С.61-64. 
the history of physics and the personalities of its creators, without awareness of the need for this knowledge by students.

A particularly important feature of the critical-reflexive style is determinism, i.e. such an approach to the analysis of processes and phenomena, in which the emphasis is on identifying the causes and mechanisms that provide a particular character of these processes. It corresponds to the essential approach in pedagogical research. The completely phenomenological approach is limited to a simple statement of facts, which often leads to a struggle not with the causes of negative phenomena, but with their consequences. In the phenomenological approach, there is often a confusion of cause and effect, as well as the incorrect definition of the causes of the phenomenon under study.

One of the means of solving the whole complex of these problems was the contextual organization of control and evaluation activities of students $^{14}$. Let's consider the implementation of this approach on the example of colloquiums-dialogues.

The main purpose of the colloquium was not so much to test the knowledge of the content of the methodology of teaching physics, but to identify the level of formation of certain professional skills associated with the technologization of the educational process in physics, the level of methodological development of the student, which contributed to his or her self-identification.

Self-identification is based on self-knowledge, whose main core is reflexive activity, so in the preparation and conduct of classes, the selection of content and organization of educational activities of students were carried out in such a way that they formed an adequate self-esteem. Mastering contextually selected content taught the student to meaningful construction of the educational process in physics in the general education school, to self-regulation of their own behavior in accordance with its real capabilities and qualities ${ }^{15}$.

14 Дмитриева В. Самойленко П. Модульная технология обучения и контроль результатов учебной деятельности по физике. Наукові записки Кіровоградського державного педагогічного університету імені Володимира Винниченка. Вип.. 66. Серія: Педагогічні науки. Кіровоград : РВВ КДПУ ім. В. Винниченка. 2006. Ч. 1. С. 61-64.

15 Іваницький O.I. Професійна підготовка майбутнього вчителя фізики в умовах інформаційно-освітнього середовища: монографія. Запоріжжя: ЗНУ, 2014. 230 с. 
The Colloquium-dialogue focused on the professional orientation of the response. The students must show specific knowledge on the organization of students' activities, knowledge of the educational process in physics, to show methodical creativity and a high degree of independence in preparing for the answer, the ability to design and compare the technology of teaching physics, knowledge of comparative analysis techniques, to express their own attitude to a particular technology, to show the ability to argue their point of view. The ability of students to competently, logically and evidently present the content of the question and consistently build an answer is also checked.

The form of the Colloquium-dialogue is caused by the need to fully disclose the capabilities of students to technologize the educational process in physics, to increase their activity, to mobilize creativity. The draw determines the «teacher» and «student», dialogic pairs are formed. With the criteria for assessing the quality and form of the Colloquium, students are acquainted in advance.

During the Colloquium, each pair prepares to answer autonomously from each other (answer the same question). During the answer to the question, the role of the «student» is traditional, unlike the role of the «teacher», who needs to correctly ask the question, constructively analyze the answer according to certain quality criteria.

Answer levels are determined collectively by a given pair of students and a teacher for each criterion.

The results of the Colloquium-dialogue enable the teacher to correct and track the results at the stage of final control.

Thus, in the context of the contextual approach to the training of future teachers of physics are undergoing significant changes in the activities of the teacher and students. In particular, during the monitoring and evaluation of learning outcomes of students contextnode of presentation is based on own teaching experience of the students gained in the study of the theory and methods of teaching physics and teaching practice. At the same time, the contextual approach to the professional training of future physics teachers provides more transparent and understandable criteria for students to assess their educational achievements. 
An important method for monitoring and evaluation activities is a computer. Professional training of the future physics teacher to using a computer to provide feedback is multidimensional. Technologies of computer control of students' knowledge is built in computer monitoring programs that allow the physics teacher to conduct current and final control of knowledge and skills, and appropriate methods of educational activities of students acquired in the process of learning physics. There are usually test programs with a choice of answers. These programs allow you to quickly assess and analyze the knowledge of large groups of students and print the results on the printer. Some programs conduct statistical analysis of students' answers, allowing the teacher of physics to understand which parts of the course require a more qualitative elaboration or repetition. Future teachers of physics must be taught to carry out preliminary treatment of educational material, which allows you to use a wide range of control computer programs diagnostic, evaluation and correction. For this purpose, in the study of the physics concept or law, a group of ways of educational activity is allocated, the correct implementation of which by the student indicates the assimilation of this concept (law) at the reproductive cognitive level.

Let's consider the invariant of the construction of the standard of assimilation on the example of the study of the concept of inert mass.

First, the signs of assimilation of the concept in the language of ways of educational activity are formulated. For the concept of inert mass $(\mathrm{m})$ signs of assimilation are:

$m_{1}$ - the ability to reproduce the definition of mass as a measure of inertia;

$m_{2}$ - the knowledge of the ratio $m_{1} / m_{2}=a_{2} / a_{1}$, the ability to reproduce it;

$m_{3}$ - the ability to solve the simplest problems of finding the mass ratio behind the known accelerations using the ratio $m_{1} / m_{2}=a_{2} / a_{1}$;

$m_{4}$ - the ability to solve body weight problems using the ratio $m_{1} / m_{2}=a_{2} / a_{1}$

$m_{5}$ - the ability to carry out direct mass measurements using lever scales;

$m_{6}$ - the ability to make direct mass measurements with a dynamometer. 
Assimilation of the set of features $\mathrm{m} 1 \ldots \mathrm{m} 6$ is an indicator of the assimilation of the concept of inert mass at the reproductive level (at this stage of training). The concept of inert mass can be symbolically represented as follows:

$\mathrm{m}\left[\left(m_{1} \Lambda m_{2}\right) \Lambda\left(m_{3} \Lambda m_{4} \Lambda m_{5} \Lambda m_{6}\right)\right]$.

Possession of students ways of activity associated with the signs of $m_{1} \Lambda m_{2}$ indicates the initial acquaintance with the concept.

The test diagnostic tasks is constructed on the base of the selected structure of concepts and used in the application monitoring software to monitor the formation of basic concepts and laws, and related correctional programs, as well as thematic control.

\section{CONCLUSIONS}

The contextual approach to professional training of future teachers of physics is a consistent combination of the traditional study of humanitarian and socio-economic disciplines with the integration of educational, scientific and pedagogical activity of students, which is an implementation of a dynamic model of their learning activities from the academic activities of the academic type (in lecture form) through quasiprofessional (role-playing and business games) and pedagogical (scientific research, pedagogical practice) to actually teaching. The basic unit of activity of the student and the teacher in contextual training becomes not «a portion of information», and the pedagogical situation in all the subject and social uncertainty and inconsistency. The system of problematic pedagogical and methodological situations allows to develop dialectically contradictory content of teaching in dynamics and thus provide objective prerequisites for the formation of theoretical and practical pedagogical thinking of the future teacher of physics. The developed model of contextual learning is characterized by a significant expansion of the content of propaedeutic pedagogical training of future teachers of physics, the creation of additional opportunities for individualization of training (through the introduction of elective subjects), the widespread using of pedagogical and methodological situations and tasks as the core of acmeological technologies of professional training of teachers of physics. The application of the contextual approach aims students at independent planning and 
correction of their own educational trajectory, constantly puts before the choice of tasks of different levels of complexity. Constant comparison of student self-assessment with the assessment of fellow students and teachers increases the effectiveness of self-control, positive implementation of the Self-concept, increases self-regulation of their own learning activities. The contextual approach to the professional training of the future teacher of physics provides more transparent and clear for students criteria of an assessment of their educational achievements.

\section{SUMMARY}

The article deals with the modernization of professional training of future teachers of physics on the basis of contextual approach. A model of contextual learning based on the expansion of the content of propaedeutic pedagogical training of future teachers of physics, the creation of additional opportunities for individualization of training (through the introduction of elective subjects), the widespread using of pedagogical and methodological situations and tasks as the core of acmeological technologies of professional training of teachers of physics.

\section{REFERENCES}

1. Вербицкий А. А. Активное обучение в высшей школе: контекстный поход. Москва : Высшая школа, 1991. 207 с.

2. Вербицкий А. А. Контексты содержания образования. М.: РИЦ МГОПУ им. М. А. Шолохова, 2003. 80 с.

3. Вербицкий А. А. Концепция знаково-контекстного обучения в вузе Вопросы психологии. 1987. № 5. С.31-39.

4. Дмитриева В. Самойленко П. Модульная технология обучения и контроль результатов учебной деятельности по физике. Наукові записки Кіровоградського державного педагогічного університету імені Володимира Винниченка. Вип.. 66. Серія: Педагогічні науки. Кіровоград : РВВ КДПУ ім. В. Винниченка. 2006. Ч. 1. С.61-64.

5. Закон України «Про вищу освіту» від 01.07.2014 № 1556-VII. URL: zakon.rada.gov.ua/go/1556-18.

6. Закон України «Про освіту» від 05.09.2017 № 2145-VIII. URL: zakon.rada.gov.ua/go/2145-19. 
7. Іваницький О. I. Інноваційні технології навчання фізики. Навчальний посібник. Запоріжжя : «Диво», 2007. 99 с.

8. Іваницький О. І. Моделювання професійної діяльності у фаховій підготовці майбутнього вчителя фізики. Зб. наук. праць К-ПНУ. Серія педагогічна / редкол.: П. С. Атаманчук (голова, наук. ред.) та ін. Кам'янець-Подільський : К-ПНУ, 2013. Вип. 19. C. 277-280.

9. Іваницький О. І. Формування соціокультурної компетентності майбутнього вчителя фізики на засадах контекстного підходу. Збірник наукових праць Кам'янець-Подільського національного університету імені Івана Огієнка. Серія педагогічна. Кам'янецьПодільський : К-ПНУ, 2011. Вип. 17. С. 273-278.

10. Іваницький О. І., Ткаченко С. Г. Технології навчання фізики: навчальний посібник. Запоріжжя : ЗНУ, 2010. 252 с.

11. Іваницький О. I. Методичні завдання як ефективний засіб формування методичної компетентності майбутніх учителів фізики. Зб. наук. праць К-ПНУ. Серія педагогічна. Вип. 19. Інноваційні технології управління якістю підготовки майбутніх учителів фізикотехнологічного профілю. К-ПНУ, 2014. С. 268-271.

12. Іваницький О. І. Професійна підготовка майбутнього вчителя фізики в умовах інформаційно-освітнього середовища: монографія. Запоріжжя: ЗНУ, 2014. 230 c.

13. Концепція розвитку педагогічної освіти. URL:https://mon.gov.ua/storage/app/uploads/public/5b7/bb2/dcc/5b7bb2 dcc424a809787929.pdf.

14. Попков В. А., Коржуев А. В. . Дидактика высшей школы. Москва : Издательский центр «Академия», 2008. 224 с.

15. Чернилевский Д. В. Дидактические технологии в высшей школе. Москва :ЮНИТИ-ДАНА, 2002. 437 с.

\section{Information about the author: Ivanytsky O. I.,}

Doctor of Educational Sciences, Professor,

Zaporizhzhia National University 66, Zhukovsky str., Zaporizhzhia, 69000, Ukraine 